\title{
Pass-Through of Imported Input Prices to Domestic Producer Prices: Evidence from Sector-Level Data
}

\author{
JaeBin Ahn*, Chang-Gui Park ${ }^{* *}$, Chanho Park ${ }^{* * *}$
}

The views expressed herein are those of the authors and do not necessarily reflect the official views of the Bank of Korea. When reporting or citing this paper, the authors' names should always be explicitly stated.

* Economist, Research Department, International Monetary Fund, 700 19th st NW, Washington, DC 20431, USA, E-mail: jahn@imf.org.

** Head, Economic Research Team, Daejeon \& Chungnam Branch, the Bank of Korea, 65, Dunsanbuk-ro, Seo-Gu, Daejeon, Repubic of Korea, E-mail: cgpark@bok.or.kr.

*** Corresponding author. Director, International Finance Division, International Department, the Bank of Korea, 39, Namdaemun-ro, Jung-gu, Seoul, Republic of Korea, E-mail: chanhopark@bok.or.kr.

We are especially grateful to Woon Gyu Choi, Seryoung Park, Kum Hwa Oh, and Steve Phillips for their very helpful comments. The views expressed in this paper are those of the authors and should not be attributed to the Bank of Korea or the International Monetary Fund. 


\section{Contents}

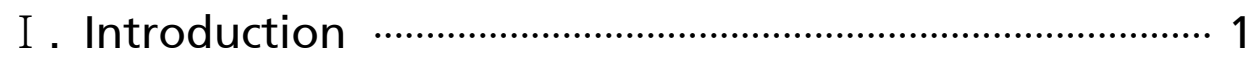

II. Econometric Framework ………………………………..... 7

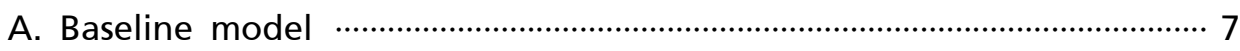

B. Empirical strategy

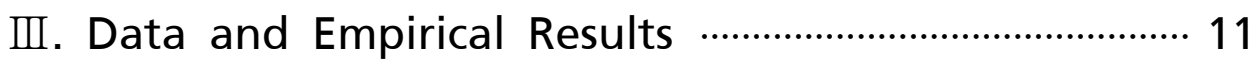

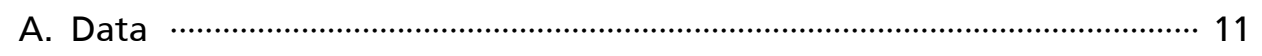

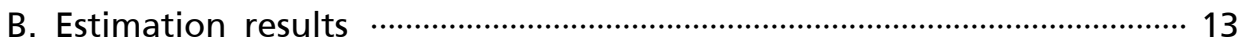

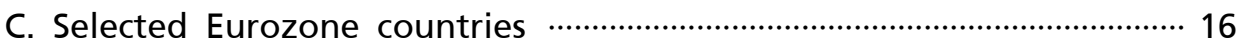

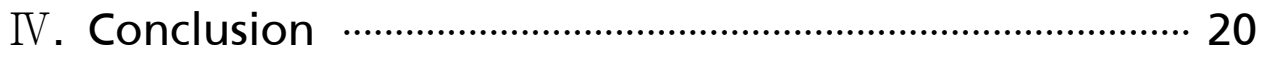

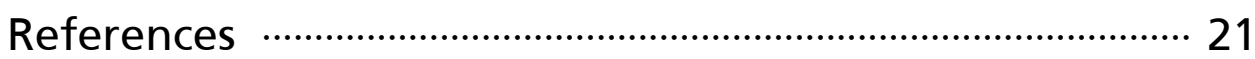




\section{Pass-Through of Imported Input Prices to Domestic Producer Prices: Evidence from Sector-Level Data}

Motivated by stylized facts pointing to a dominant role of imported inputs in transmitting external price shocks to domestic prices, this paper zooms in to study the pass-through of imported input costs to domestic producer prices. Our approach constructs effective input price indices from sector-level price data combined with sector-level information on input-output linkages. Applying an error correction model specification to sector-level output and input prices, the long-run pass-through rate of effective imported input costs to domestic producer prices is estimated to be around 70 percent in Korea and almost 100 percent in selected European countries.

Keywords: Exchange rate pass-through, Imported input cost pass-through, Inflation

JEL classification: E3, F3, F4 


\section{I . Introduction}

Countries import not just goods and services but also prices quoted. The so-called "imported inflation" stems from prices of imported goods that influence domestic price levels; they affect the consumer price index (CPI) via imported consumption goods included in the CPI, or the producer price index (PPI) through imported raw and intermediate inputs used for domestic production with possible second-round effects on the CPI.1)

Understanding the effect of import price changes on domestic prices is crucial for various reasons. From a practical point of view, for instance, it is essential for central bankers in forecasting inflation, for which external shocks such as commodity price or exchange rate movements should be taken into account. Moreover, the degree of exchange rate pass-through to domestic prices via imported goods is a key determinant of the optimal exchange rate policy regime (e.g., Corsetti and Pesenti, 2005; Devereux and Engel, (2003, 2007); Obstfeld and Rogoff, 2000).

When it comes to quantitative assessment of import price pass-through to domestic prices, there are strong reasons to believe that the imported inputs would be the dominant channel through which import prices affect domestic price levels. Consumption goods are only a small portion of total imports in most countries. In the case of Korea, the main focus of this paper, consumption goods tend to constitute at most a little over 10 percent of total imports (Figure 1).

Together with the fact that the CPI basket of goods is composed mainly of domestic goods2), this implies that the imported consumption goods channel is limited by nature. Indeed, the sheer size of raw and intermediate inputs in total imports makes the official import price index largely reflect prices of imported inputs, with a correlation coefficient of 0.97 between monthly change of the aggregate import price index and that of the aggregate imported input price index in Korea (Figure 2). For this reason alone, it may not be too much to state

1) Imported (dis)inflation has been particularly at the center of recent policy discussions in European countries (e.g., Iossifov and Podpiera, 2014; IMF, 2015).

2) Although the exact share of imported goods in the CPI basket in Korea is not readily available, our informal interview with the Statistics Korea (KOSTAT) suggests that imported goods cover around $7 \%$ of the CPI basket. 
Figure 1: Imports of Goods by End-Use Category

(In percent of total Korean imports over the period 1999-2014)

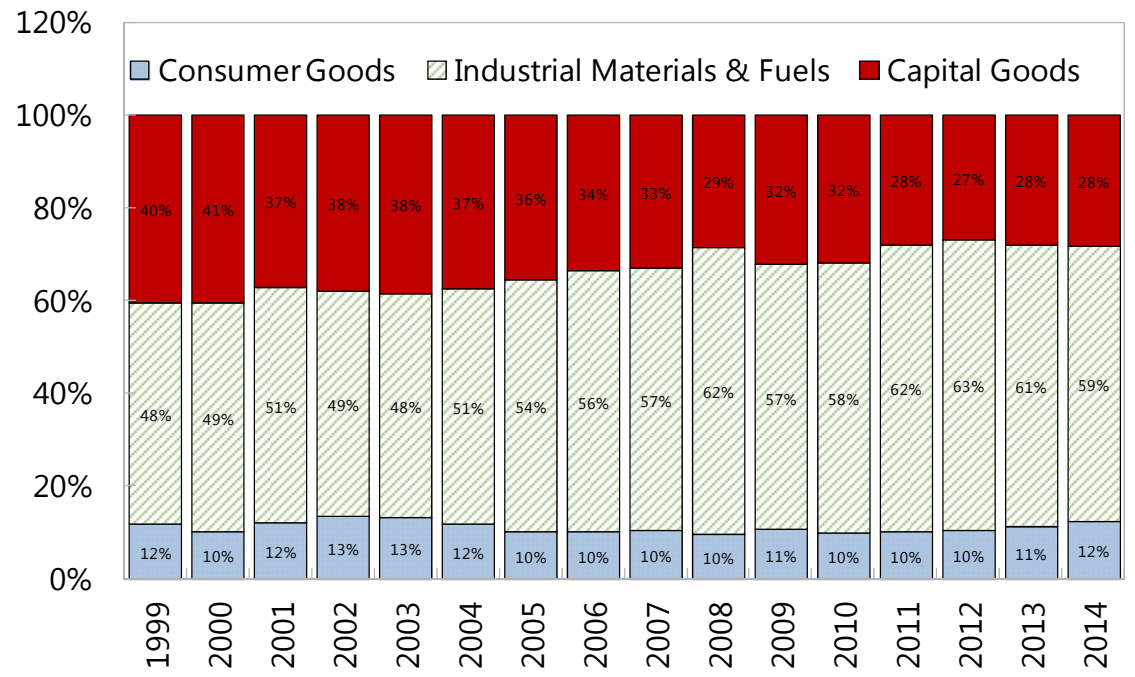

Sources: Korea Customs; CEIC

Figure 2: Imports Price Index in Korea (Monthly inflation rate in percent; 1999-2014)

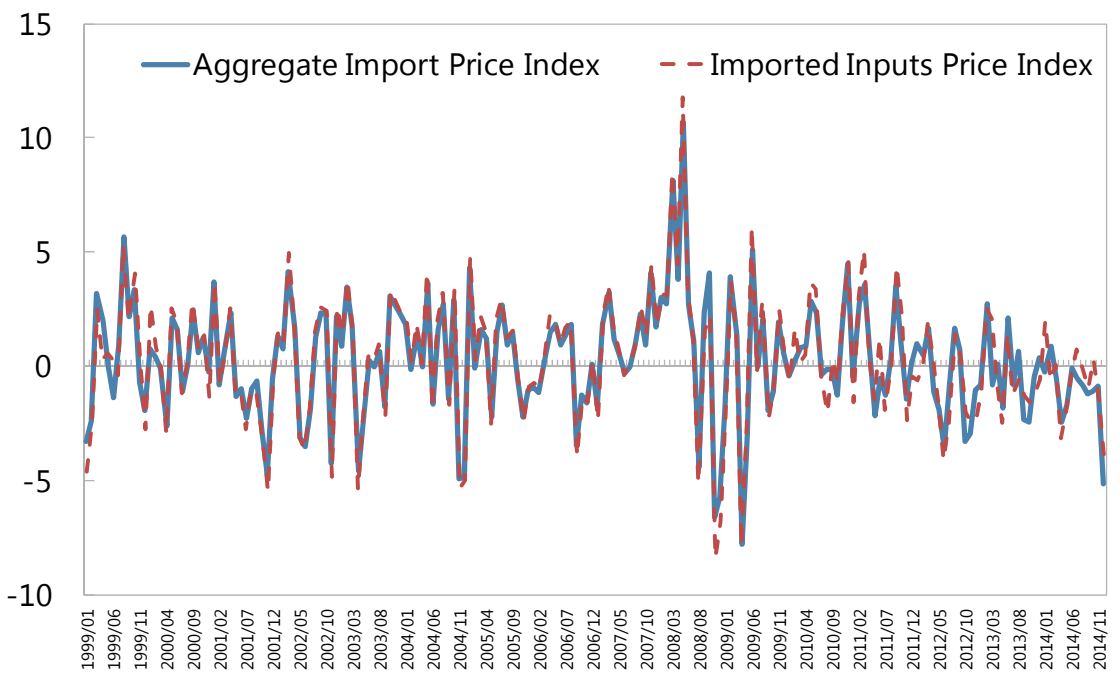

Sources: Bank of Korea 
Figure 3: Imported Inputs Use in Korean Manufacturing

(In percent of total intermediate inputs use in 2000 and 2010)

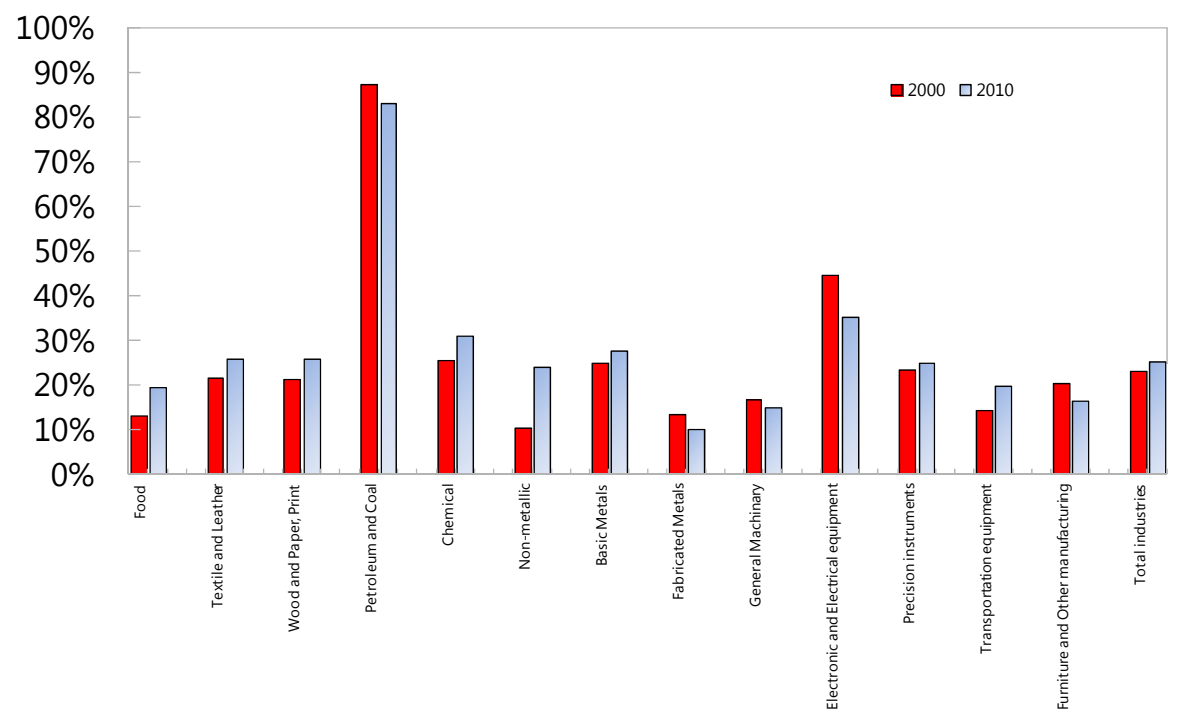

Sources: Bank of Korea

that any attempt to infer the role of imported consumption goods in this context using the import price index will be futile at best.

In contrast to the small share of imported consumption goods in final consumption, imported inputs make up a sizable portion of input use in domestic production. The share of imported inputs in total intermediate inputs varies across industries, but according to the Korean Input-Output (IO) table, it has been stable around 25 percent in terms of both the average across industries and the aggregate (Figure 3). To the extent that the effect of a given factor price on producer prices is proportional to its share in total cost, one may roughly infer that a quarter of producer price levels can be explained by imported input prices. Or, to put it differently, a change in imported input prices may feed into a change in producer prices by a scale factor of a quarter. Indeed, monthly change of the aggregate producer price index is strongly correlated with that of the aggregate import price index with a correlation of 0.63 , while the import price index appears to be about four times more volatile than the producer price index (Figure 4 and Figure 5). 
Figure 4: Import Price and Producer Price Index in Korea (Monthly inflation rate in percent; 1999-2014)

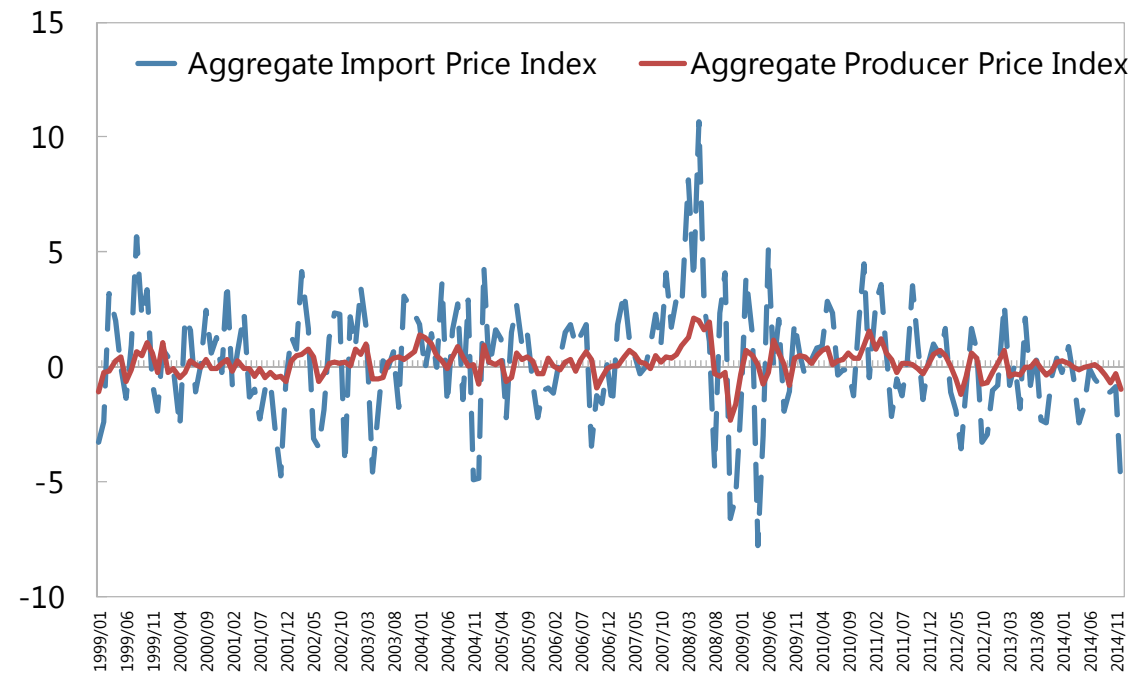

Sources: Bank of Korea

Figure 5: Inflation Dynamics in Korea

(Yearly inflation rate in percent; 2000-2015)

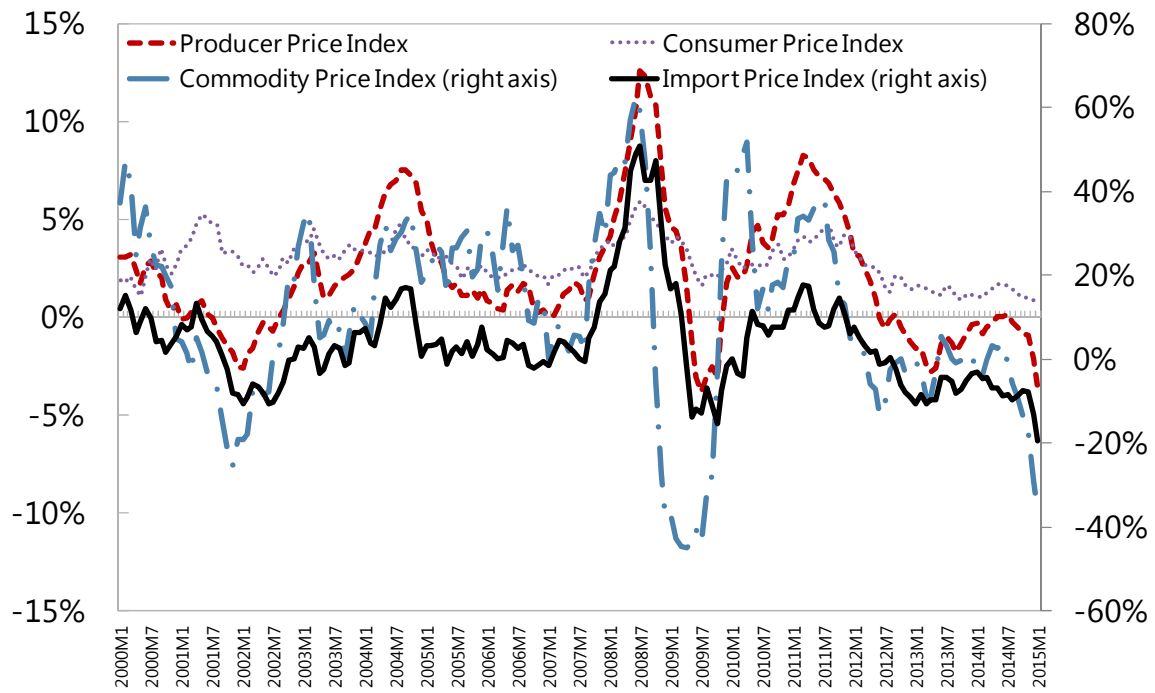

Sources: Bank of Korea; Commodity Price Index from IMF's WEO database 
Based on these observations, this paper focuses exclusively on the role of imported inputs in affecting domestic producer prices, and estimates the degree of the imported input cost pass-through to producer prices by applying an error correction model (ECM) specification to sector-level monthly frequency data.

A notable departure of this paper from the literature is to investigate the import price pass-through to domestic prices instead of the much-studied exchange rate pass-through (ERPT) to import prices or CPIs. Given that exchange rates first pass through to import prices, which in turn affect domestic prices, the approach in this paper is an essential step to understanding and gauging the ultimate pass-through of exchange rates to domestic prices, taking observed changes in import prices as given. ${ }^{3)}$ Moreover, this approach allows for a broader interpretation since import price shocks are not restricted to those resulting from exchange rate movements but also include commodity price shocks.

Another distinct feature of this study is to single out the imported input channel of the pass-through. There is an emerging literature that finds a dominant role of this particular channel in facilitating the exchange rate pass-through to domestic prices or dampening the effects on export prices (Ahn and Park, 2014; Amiti et al., 2014). Specifically, the current study employs the sector-level import price index combined with the bilateral sector-level Input-Output (IO) table to construct the sector-level imported input price index, thereby directly exploring the relationship between imported input prices and domestic prices at the sector level.

In this regard, this study is most closely related to Auer and Mehrotra (2014) who similarly construct the sector-level imported input price index to study inflation spillovers via trade linkages in Asian countries. ${ }^{4}$ ) Unlike their study, the main goal of the current study is to estimate the degree of imported input cost

3) Among the vast literature on ERPT, Campa and Goldberg (2005) study exchange rate pass-through to import prices using sector-level cross-country data, while Goldberg and Campa (2010) consider pass-through to CPIs across countries. For previous studies on ERPT in Korea, see Cha (2012) and Kim (2012) who also focus on the role of imported inputs and Lee (1997) who considers the role of market structure in determining the degree of ERPT to import prices.

4) The sector-level IO table has been widely used in constructing the sector-level input tariff rates (e.g., Amiti and Konings, 2007; Topalova and Khandelwal, 2012), but, to our knowledge, Auer and Mehrotra (2014) is the only preceding study that applies the idea to construct the sector-level imported input price levels. 
pass-through to domestic producer prices, effectively separating out the contributions from markup adjustments and the cost share of imported inputs. Along the way, we also provide a separate estimate of the pass-through rate from domestic input cost to producer prices. We note that the error correction model specification employed in the present paper provides a consistent and more efficient estimate than the estimation model with difference-stationary data when the variables of interest are considered nonstationary and cointegrated, as in the current context.

The main findings from the error correction model estimation results suggest that, once the share of imported inputs in total costs is correctly accounted for, a 1 percent change in the effective imported input prices leads to, on average, a 0.4 percent change in domestic producer prices in the short run, and to a 0.7 percent change in the long run in Korea, with the speed of the adjustment around 1.5 percent per month. These results are robust to estimation from quarterly frequency data, alternative treatments for domestic input cost and unit labor cost measures, the length of lagged terms, and other variants. A subsequent investigation on the possible heterogeneity in the degree of pass-through across sectors shows that the homogeneity assumption cannot be rejected, in favor of the dynamic fixed effects (DFE) estimator over the pooled mean group (PMG) estimator.

Noting that the current methodology can be applied to any country with an available set of data on sector-level producer and import prices as well as IO tables, we extend the analysis to three European countries-France, Germany, and the Netherlands - that satisfy such data requirements. We find that these economies have a higher pass-through rate than Korea. This exercise demonstrates the generalizability of the present methodology, but at the same time it suggests substantial heterogeneity in the degree of import price pass-through across countries, potentially reflecting different market structures.

The remainder of the paper is organized as follows. Section II introduces an illustrative theoretical model and discusses the empirical strategy. Section III describes the data and summarizes empirical findings, and Section IV concludes the paper. 


\section{II . Econometric Framework}

\section{A. Baseline model}

This section introduces a baseline model, which is a simple variant of the traditional model in the exchange rate pass-through literature (e.g., Burstein and Gopinath, 2014; Campa and Goldberg, 2005). Profit maximizing firms will set the price as a markup over marginal cost:

$$
\ln P_{i t}=\ln \mu_{i t}+\ln M C_{i t}
$$

Considering the use of imported inputs explicitly as in Ahn and Park (2014), marginal cost is assumed to take a labor augmenting Cobb-Douglas form with domestic and imported intermediate goods, and labor, as inputs:

$$
\ln M C_{i t}=\alpha_{i} \ln \left(D O M_{i t}\right)+\beta_{i} \ln \left(I M P_{i t}\right)+\gamma_{i} \ln \left(U L C_{i t}\right)+\varepsilon_{i t},
$$

where $D O M_{i t}, I M P_{i t}, U L C_{i t}$ are domestic intermediate input price, imported intermediate input price, unit labor cost, respectively-all denominated in local currency unit -and $\varepsilon_{i t}$ captures random optimization error. The share of each input in total costs is accordingly denoted as $\alpha_{i}, \beta_{i}$, and $\gamma_{i}$.

Combining equations ( 1 ) and (2), the optimal pricing equation is expressed as:

$$
\ln P_{i t}=\ln \mu_{i t}+\alpha_{i} \ln \left(D O M_{i t}\right)+\beta_{i} \ln \left(I M P_{i t}\right)+\gamma_{i} \ln \left(U L C_{i t}\right)+\varepsilon_{i t}
$$

The sector-level aggregate will be the weighted average of firm-level components, which will depend on the distribution of individual firm-level prices within each industry. For notational convenience, we consider each sector to be populated by identical firms so that the sector-level price is expressed exactly as the firm-level price equation in (3), with the subscript $i$ denoting each sector from this point on.

In general, the property of markups is governed by a specific form of sector-level demand curve, or more precisely, the price elasticity of demand. Allowing the degree of markup adjustment in response to cost shocks to vary across the source of such shocks, markups can be assumed to take the following form:

$$
\ln \mu_{i t}=\ln \mu_{i}+\delta_{i}^{d o m} \cdot \alpha_{i} \ln \left(D O M_{i t}\right)+\delta_{t}^{i m p} \cdot \beta_{i} \ln \left(I M P_{i t}\right)+\delta_{i}^{u l c} \cdot \gamma_{i} \ln \left(U L C_{i t}\right)
$$


As a result, equation (3) is rewritten as:

$$
\begin{aligned}
\ln P_{i t}= & \left(1+\delta_{i}^{d o m}\right) \cdot \alpha_{i} \ln \left(D O M_{i t}\right)+\left(1+\delta_{i}^{i m p}\right) \cdot \beta_{i} \ln \left(I M P_{i t}\right) \\
& +\left(1+\delta_{i}^{u l c}\right) \cdot \gamma_{i} \ln \left(U L C_{i t}\right)+F E_{i}+\varepsilon_{i t}
\end{aligned}
$$

where the sector-specific term, $F E_{i}$, effectively absorbs any other determinants of the sector-level producer price including the sector-specific component of markup, $\ln \mu_{i}$. In practice, it also reflects that sector-level producer prices are expressed in index form and thus cannot be directly compared across sectors.

According to equation (4), the degree of imported input cost pass-through is given as $\left(1+\delta_{i}^{i m p}\right) \cdot \beta_{i}$ : first, depending on the share of imported inputs in total costs, only a fraction (i.e., $\beta_{i}$ ) of the imported input cost shocks will be effective. Once this is accounted for, the markup adjustment (i.e., $1+\delta_{i}^{i m p}$ ) will then determine the rest of the cost pass-through. A variable markup is a well-known source of incomplete cost pass-through (i.e., $\delta_{i}^{i m p}<0$ ), whereas a constant markup is consistent with complete (effective) cost pass-through (i.e., $\delta_{i}^{i m p}=0$ ). Our goal in

this paper is to identify the extent of such markup adjustments (i.e., $1+\delta_{i}^{i m p}$ ) conditional on changes in effective input costs, by accounting for the share of imported inputs in total costs separately.

\section{B. Empirical strategy}

For the baseline pricing equation above to be taken to the empirical level, there are several things to be discussed. As for linking the model and data, the sector-level producer price $\left(P_{i t}\right)$ corresponds to the sector-level producer price index that is available from the data. On the other hand, the sector-specific imported input price $\left(I M P_{i t}\right)$, which can be regarded as a composite of multi-sector imported goods prices, is not readily available from the data, and thus needs to be constructed. Our strategy is to use the Input-Output (IO) table together with sector-level import price data to construct the weighted average of sector-level imported input prices for each output sector, $i$. Specifically, we take $\beta_{i j}$, 
the share of imported inputs from sector $j$ in total inputs used for sector $i$ 's production, from the IO table, and take the weighted average of import prices across input sectors to construct the effective imported input price as:

$$
\ln \left(E I M P_{i t}\right)=\beta_{i} \ln \left(I M P_{i t}\right)=\beta_{i} \sum_{j}\left(\beta_{i j} / \beta_{i}\right) \ln \left(I_{j t}\right)
$$

where $\sum_{j} \beta_{i j}=\beta_{i}$ and $I_{j t}$ is $j$ sector's import price index available from the sector-level import price data. Likewise, the sector-specific effective domestic input price can be constructed from the IO table and the sector-level domestic producer price index as:

$$
\ln \left(E D O M_{i t}\right)=\alpha_{i} \ln \left(D O M_{i t}\right)=\alpha_{i} \sum_{j}\left(\alpha_{i j} / \alpha_{i}\right) \ln \left(P_{j t}\right)
$$

where $\sum_{j} \alpha_{i j}=\alpha_{i}$ with $\alpha_{i j}$ being the share of domestic inputs from sector $j$ in total inputs used for sector $i$ 's production that is available from the IO table. Lastly, $\gamma_{i}$, the share of labor costs in total inputs used for sector $i$ 's production that is available from the IO table, can be combined with sector-level ULC data to measure the effective unit labor cost term:

$$
\ln \left(E U L C_{i t}\right)=\gamma_{i} \ln \left(U L C_{i t}\right)
$$

Turning to the econometric specification, we note that a dynamic version of equation (4) that reflects potential price rigidity will be appropriate in practice. For instance, an ARDL $(1,1)$ version of equation (4) is expressed as:

$$
\begin{aligned}
\ln P_{i t}= & \Sigma_{j=0}^{1}\left[\left(1+\delta_{i j}^{d o m}\right) \cdot \alpha_{i} \ln \left(D O M_{i t-j}\right)+\left(1+\delta_{i j}^{i m p}\right) \cdot \beta_{i} \ln \left(I M P_{i t-j}\right)\right. \\
& \left.+\left(1+\delta_{i j}^{u l c}\right) \cdot \gamma_{i} \ln \left(U L C_{i t-j}\right)\right]+\left(\sigma_{i}\right) \ln P_{i t-1}+F E_{i}+\varepsilon_{i t}
\end{aligned}
$$

Further, producer price and input price levels tend to be nonstationary. When they are also cointegrated, a valid econometric tool to estimate will be an error correction model (ECM). With some algebra, equation (4') can be rewritten in ECM form as: 


$$
\begin{aligned}
\Delta \ln P_{i t}= & {\left[\left(1+\delta_{i 0}^{\text {dom }}\right) \cdot \Delta \ln \left(E D O M_{i t}\right)+\left(1+\delta_{i 0}^{i m p}\right) \cdot \Delta \ln \left(E I M P_{i t}\right)\right.} \\
& \left.+\left(1+\delta_{i 0}^{u l c}\right) \cdot \Delta \ln \left(E U L C_{i t}\right)\right] \\
& +\left(e c_{i}\right)\left[\ln P_{i t-1}-\theta_{i}^{i m p} \ln \left(E I M P_{i t-1}\right)-\theta_{i}^{d o m} \ln \left(E D O M_{i t-1}\right)\right. \\
& \left.-\theta_{i}^{u l c} \ln \left(U L C_{i t-1}\right)\right]+\varepsilon_{i t}
\end{aligned}
$$

where $\left(1+\delta_{i 0}^{k}\right)$ is the short-run effective cost pass-through parameter and $\theta_{i}^{k}$ is the long-run pass-through parameter for $k=d o m$, imp, ulc, and $e c_{i}$ denotes the speed of adjustment. We note that the long-run pass-through parameter, $\theta_{i}^{k}$, and the speed of adjustment parameter, $e c_{i}$, correspond to $\left(2+\delta_{i 0}^{k}+\delta_{i 1}^{k}\right) /-\left(e c_{i}\right)$ and $\sigma_{i}-1$ from the ARDL $(1,1)$ version in equation (4'), respectively. In practice, when the estimated coefficient on the speed of adjustment, $e c_{i}$, is negative, it will suggest the presence of a cointegration relationship between the variables considered, whereas nonnegative estimates will reject it in which case the model should be rather estimated in, for instance, first difference form possibly with lagged dependent variable terms.

The specification in equation (5) allows for possible heterogeneity in the degree of effective cost pass-through across sectors. Conceptually, it is plausible that sector-specific market structure may lead to different pricing behaviors especially in the short run, which may stem from differing degrees of competition in output markets, and hence, result in sector-specific price elasticity of demand.

Assuming no heterogeneity in $\delta_{i}^{j}$ across sectors, one can simply estimate the ECM in equation (5) in a pooled manner with sector-level fixed effects (i.e., a dynamic fixed effects model (DFE)), which will be a consistent and efficient estimator. When there is indeed heterogeneity in $\delta_{i}^{j}$ across sectors, however, a pooled mean group estimator (PMG) should be preferred since it will provide consistent and efficient estimates of the average pass-through coefficient (Pesaran, Shin, and Smith, 1999). This can be formally tested by implementing the Hausman test to check the validity of the null hypothesis that there is no heterogeneity, in which case the DFE estimator should be preferred. 


\section{Data and Empirical Results}

\section{A. Data}

The primary data employed in this study come from the Statistics Database at the Bank of Korea (Economic Statistics System; ECOS) that is publicly accessible on the web (ecos.bok.or.kr). These include the Korean sector-level producer price index and sector-level import price index both at the monthly as well as quarterly frequency in local currency unit, and the Input-Output (IO) tables in benchmark years-1995, 2000, 2005, and 2010. The sector-level quarterly unit labor cost (ULC) data in Korea comes from the Korea Productivity Center (www.kpc.or.kr), of which availability restricts the main sample of the study to 1999 onwards for a total of thirteen 2-digit level manufacturing sectors.5) The monthly ULC series is generated by applying the cubic spline interpolation method to the quarterly data.

When constructing the effective input prices, the bilateral sector-level imported and domestic input coefficients are taken from each corresponding period's benchmark IO table for the imported input and domestic input use tables, respectively. Along the way, we rescale input coefficients in such a way that the respective share of imported inputs, domestic inputs, and labor costs sum to 1 -i.e., net of taxes, capital depreciation, etc. Regarding the domestic producer price index, we note that a given sector's producer price index will end up appearing on both the left-hand side (i.e., domestic output price) and right-hand side (i.e., domestic input price) of the equation by construction. In order to reduce a potential concern of simultaneity bias, the baseline specification will employ the effective domestic input price data that is constructed by omitting the own sector's domestic input price:

$$
\ln \left(\widetilde{E D O} M_{i t}\right)=\alpha_{i} \sum_{j \neq i}\left(\alpha_{i j} / \alpha_{i}\right) \ln \left(P_{j t}\right)
$$

5) These 13 manufacturing sectors are: Food; Textile and Leather; Wood and Paper, Print; Petroleum and Coal; Chemical; Non-metallic; Basic metals; Fabricated metals; General machinery; Electronic and Electrical equipment; Precision instruments; Transportation equipment; Furniture and other manufacturing. 


\section{Table 1: Unit Root Tests for Korean Sector-level Price Series}

\begin{tabular}{lrrrr} 
& \multicolumn{4}{c}{ p-values for } \\
\cline { 2 - 5 } & In_PPlit & In_EIPlit & In_EDOMit & In_EULCit \\
Im-Pesaran-Shin & 0.9987 & 0.9586 & 0.6789 & 0.0001 \\
$\begin{array}{l}\text { Fisher-type } \\
\quad \text { inverse chi-squared }\end{array}$ & 0.9993 & 0.9944 & 0.9006 & 0.0002 \\
$\quad$ inverse normal & 0.9990 & 0.9761 & 0.7474 & 0.0001 \\
$\quad$ inverse logit & 0.9986 & 0.9668 & 0.7303 & 0.0001 \\
$\quad$ modified inverse chi-squared & 0.9924 & 0.9807 & 0.8880 & 0.0000 \\
\hline Number of Sectors & 15 & 15 & 15 & 13 \\
Number of Periods & 240 & 240 & 240 & 187 \\
\hline
\end{tabular}

Notes: This table reports p-values for each variable from panel unit root test using Im-Pesaran-Shin or Fisher type methods. The null hypothesis is that all panels contain a unit root, while the alternative is that at least one panel is stationary.

while checking the robustness to the default case including the own sector's domestic input price.6)

$<$ Table 1> reports p-values from unit root tests for all these sorts of sector-level price indices in Korea. We implement two distinct types of unit root tests that allow for heterogeneity in the autoregressive parameters across sectors - Im, Pesaran, and Shin (2003)-type and Fisher-type - with the latter test reporting four different statistics. In essence, none of the tests can reject the null hypothesis that all the sectors contain unit roots for all the price indices except for the case of ULC.

As for the data for the selected European countries, the only difference is that all of them come from the publicly available Eurostat database; otherwise, they are processed in exactly the same way as is done for the Korean data.7)

6) For European countries considered later, we get around this potential issue by distinguishing producer prices for both domestic and foreign markets (i.e., output prices on the left-hand side) from those for domestic markets (i.e., input prices on the right-hand side) that are separately available from the Eurostat database.

7) Only these three countries have the comprehensive data coverage from the Eurostat database at a comparable level to that of the Korean data. Specifically, the Netherlands has perfect coverage for all nineteen 2-digit level manufacturing sectors (Nace Rev. 2) over the period between 2005 and 2014, whereas even France and Germany have missing import price data for some sectors depending on the year. 


\section{B. Estimation results}

$<$ Table 2> reports the baseline error correction model estimation results for Korea. Columns (1) and (3) are from the dynamic fixed effects estimator (DFE), while columns (2) and (4) employ the pooled mean group estimator (PMG). According to unit root tests reported in $<$ Table $1>$, since the effective unit labor cost series is stationary and thus cannot be cointegrated with any other variables, it is excluded in the error correction term in all columns but is included in the short-run equation in columns (3) and (4). That is, $\theta^{u l c}$ in equation (5) is assumed to be zero in all columns, while $\delta_{i}^{u l c}$ is allowed to be nonzero in columns (3) and (4).

In column (1), the degree of the short-run cost pass-through of imported inputs into producer price is estimated to be around 23 percent, while that of domestic inputs is estimated to be around 21 percent, which values are not statistically different from each other. The estimated coefficients in the long-run relationship term show that the degree of the long-run cost pass-through of imported and domestic inputs rises to around 63 percent and 79 percent, respectively, of which the 95 percent confidence interval ranges overlap. The estimate of the error correction coefficient suggests that deviations from the long-run equilibrium relationship adjust by 1.7 percent in each month. Considering possible heterogeneity in the degree of the short run cost pass-through across sectors, column (2) runs the PMG estimator, yielding basically similar results. The Hausman test statistic suggests that the null hypothesis of homogeneity in the degree of the short-run cost pass-through across sectors cannot be rejected and thus the DFE estimator should be preferred.

Comparing columns (1) and (2) to columns (3) and (4), adding the unit labor cost in the short-run effect term has only limited effects, raising estimated pass-through coefficients slightly. In column (3), the degree of the short-run imported input cost pass-through is now estimated to be around 37 percent, while that of domestic input is estimated to be around 40 percent, which are still not statistically different from each other. The degree of the long-run cost pass-through is estimated to be around 67 percent and 86 percent for imported and domestic inputs, respectively. These also lie within each other's 95 percent 


\section{Table 2: Baseline Error Correction Model (ECM) Estimation Results for Korea}

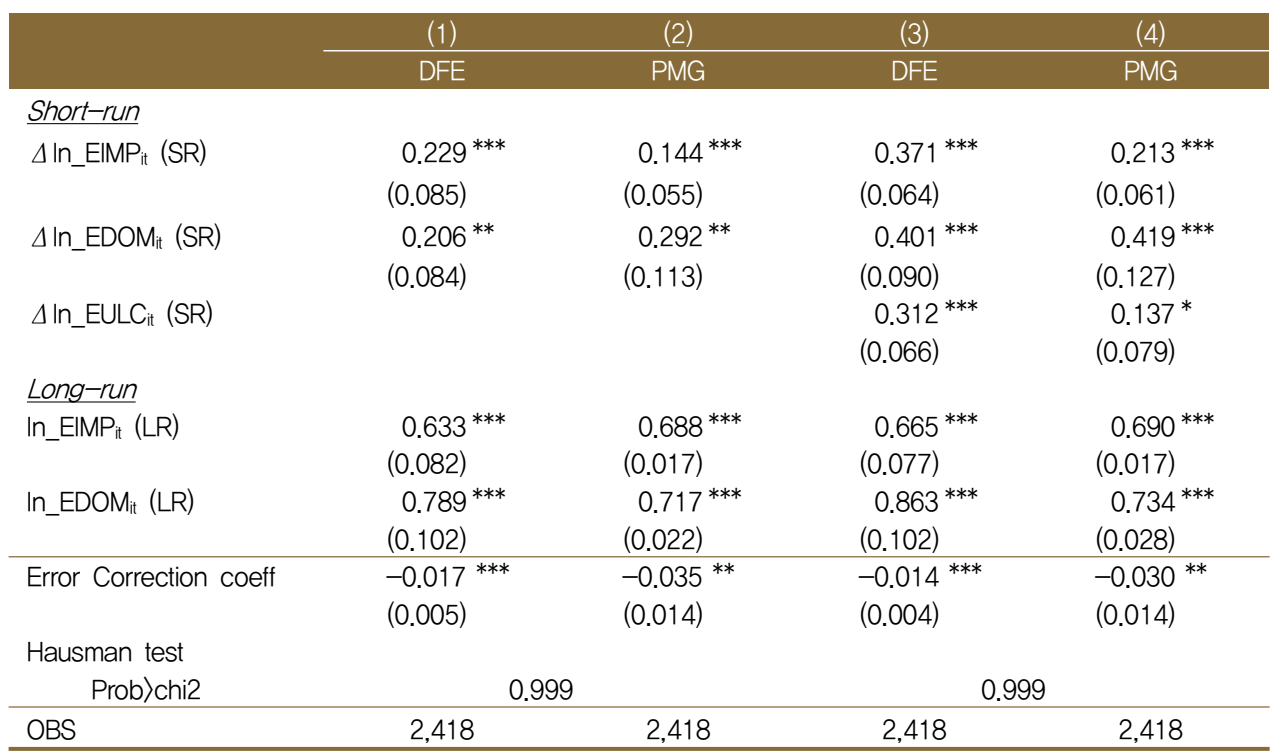

Notes: This table reports the baseline error correction model estimation results. The dependent variable in columns (1) - (4) is the sector-level monthly producer price (PPI) inflation. Independent variables include sector-level monthly effective PPI inflation (EDOM), monthly effective import price inflation (EIMP), and the error correction term. Columns (3) and (4) also include sector-level monthly effective unit labor cost inflation (EULC). Columns (1) and (3) report dynamic fixed effects estimation results, whereas columns (2) and (4) report pooled mean group estimation results. Estimates on the error correction coefficient and p-values from the Hausman test are reported at the bottom of the table. Robust standard errors are in parentheses. Significance: * 10 percent; ** 5 percent; *** 1 percent.

confidence intervals. The size of the speed of the adjustment coefficient is such that deviations from the long-run equilibrium relationship adjust by 1.4 percent in each month. Again, considering possible heterogeneity in the degree of the short run cost pass-through across sectors, column (4) runs the PMG estimator, yielding basically similar results to column (3). The Hausman test statistic suggests that the null hypothesis of homogeneity in the short-run cost pass-through across sectors cannot be rejected and hence, the DFE estimator should be the consistent and efficient estimator.

$<$ Table $3>$ checks the robustness of the baseline estimation results. Columns (1) and (2) employ quarterly frequency data using the DFE and the PMG 
Table 3: Extended Error Correction Model (ECM) Estimation Results for Korea (I)

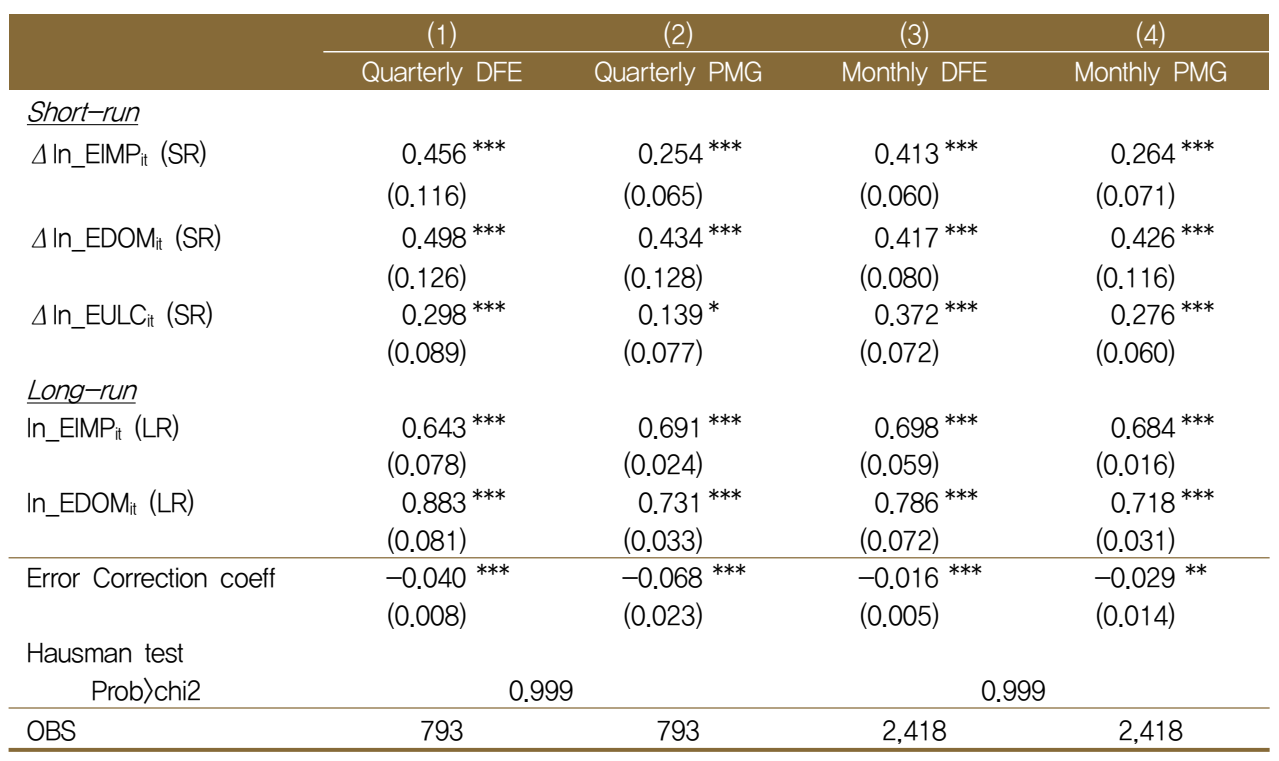

Notes: This table checks the robustness of the baseline error correction model estimation results. The dependent variable in columns (1) - (4) is the sector-level producer price (PPI) inflation. Independent variables include sector-level effective PPI inflation (EDOM), effective import price inflation (EIMP), sector-level monthly effective unit labor cost inflation (EULC) and the error correction term. Columns (1) and (2) are at quarterly frequency, while columns (3) and (4) are at monthly frequency with alternative measure on sector-level effective PPI inflation (EDOM) as described in the main text. Columns (1) and (3) report dynamic fixed effects estimation results, whereas columns (2) and (4) report pooled mean group estimation results. Estimates on the error correction coefficient and p-values from the Hausman test are reported at the bottom of the table. Robust standard errors are in parentheses. Significance: * 10 percent; ** 5 percent; *** 1 percent.

estimator, respectively. The overall results are similar to those from monthly frequency data. The DFE estimator suggests that the point estimates on the short-run cost pass-through for imported and domestic inputs are pretty similar at around 45 50 percent. The long-run cost pass-through is estimated to be around 64 percent for imported inputs and 88 percent for domestic inputs, which are statistically not different from each other. The estimated speed of the adjustment is consistent with that from monthly frequency data in that it is about three times bigger than that reported in $<$ Table $2>$. As earlier with monthly frequency data, the Hausman test cannot reject the null and thus the DFE estimator is preferred. 
Columns (3) and (4) in <Table $3>$ check the robustness to alternative measure of the effective domestic input price, which now incorporates a given sector's own producer price in constructing the composite of the domestic input price. Again, the results are overall similar to the baseline estimation results reported in <Table $2>$. In the short run, imported and domestic input cost shocks are passed through to producer prices by around 40 percent, while around 70 80 percent of them are passed through in the long run. The Hausman test supports the use of the DFE estimator.

$<$ Table $4>$ checks the robustness of the results to including additional lagged terms for both monthly data (columns (1) and (2)) and quarterly data (columns (3) and (4)). The results show richer information on the short-run dynamics without affecting the overall results obtained above.

\section{Selected Eurozone countries}

In this section, we apply the same methodology to selected Eurozone countries-France, Germany, and the Netherlands. In principle, the methodology developed above can be applied to any other country with a complete set of available data on the producer price index, import price index, unit labor cost, and the IO table, all at the sector level. We chose these three countries because they are the only countries in the Euro area with those sets of data readily available.

$<$ Table 5> reports error correction model estimation results for these three countries in a pooled manner with country-sector-level fixed effects in columns (1) and (3) and the results of using the PMG estimator in columns (2) and (4). <Table $6>$ checks the robustness by including additional lagged terms.

Several things stand out. First, comparing columns (1) and (2) to columns (3) and (4), it is obvious that the effective unit labor cost variable does not play any role in these countries, possibly reflecting noisier measures or limited variation in the series. Second, unlike the earlier results from the Korean data, the results from the DFE estimator and those from the PMG estimator tend to diverge more significantly, but the Hausman test statistic still supports the validity of the DFE 
Table 4. Extended Error Correction Model (ECM) Estimation Results for Korea (II)

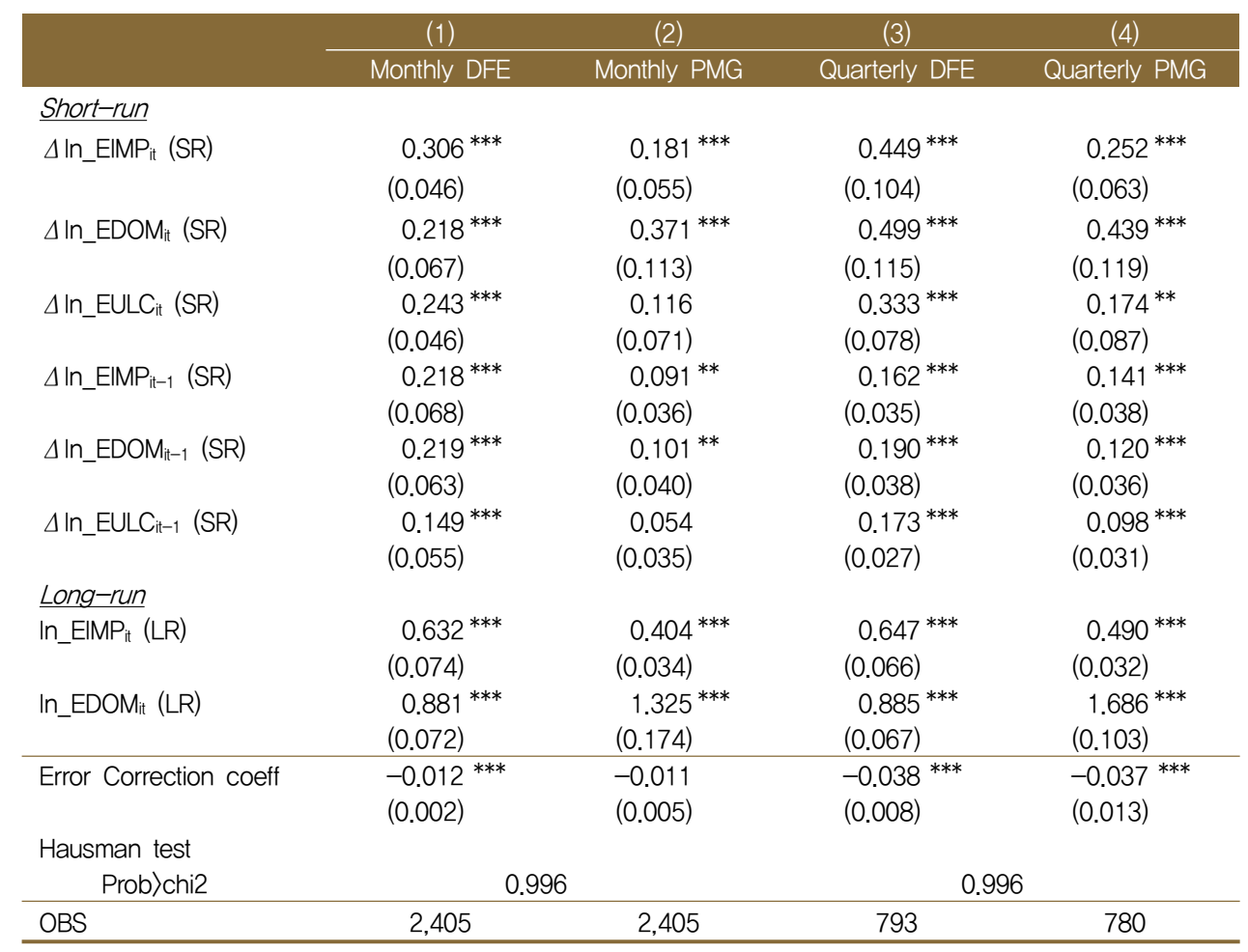

Notes: This table checks the robustness of the baseline error correction model estimation results. The dependent variable in columns (1) - (4) is the sector-level producer price (PPI) inflation. Independent variables include sector-level effective PPI inflation (EDOM), effective import price inflation (EIMP), sector-level monthly effective unit labor cost inflation (EULC) and their one-period lagged terms as well as the error correction term. Columns (1) and (2) are at monthly frequency, while columns (3) and (4) are at quarterly frequency. Columns (1) and (3) report dynamic fixed effects estimation results, whereas columns (2) and (4) report pooled mean group estimation results. Estimates on the error correction coefficient and p-values from the Hausman test are reported at the bottom of the table. Robust standard errors are in parentheses. Significance: * 10 percent; ** 5 percent; *** 1 percent.

estimator. Third, considering the suggested preference toward the DFE estimator, we note that the estimated cost pass-through coefficients from the DFE estimator in Eurozone countries tend to be significantly larger than those in Korea; the degree of short-run cost pass-through from imported inputs is around 90 percent, and the long-run coefficient is almost 1 , suggesting near-perfect cost pass-through 


\section{Table 5: Baseline Error Correction Model (ECM) Estimation Results for Selected European Countries}

\begin{tabular}{|c|c|c|c|c|}
\hline & (1) & (2) & (3) & (4) \\
\hline & DFE & PMG & DFE & PMG \\
\hline \multicolumn{5}{|l|}{ Short-run } \\
\hline$\Delta \mathrm{In} \_$EIMP $(\mathrm{SR})$ & $\begin{array}{l}0.904^{* * *} \\
(0.192)\end{array}$ & $\begin{array}{l}0.676^{* * *} \\
(0.098)\end{array}$ & $\begin{array}{l}0.904^{* * *} \\
(0.192)\end{array}$ & $\begin{array}{l}0.678^{* * *} \\
(0.098)\end{array}$ \\
\hline$\Delta \mathrm{In} \_$EDOM (SR) & $\begin{array}{c}0.563^{* *} \\
(0.242)\end{array}$ & $\begin{array}{c}0.663^{* * *} \\
(0.209)\end{array}$ & $\begin{array}{c}0.563^{* *} \\
(0.242)\end{array}$ & $\begin{array}{l}0.657^{* * *} \\
(0.207)\end{array}$ \\
\hline$\Delta \mathrm{In} \_$EULC (SR) & & & $\begin{array}{r}0.001 \\
(0.001)\end{array}$ & $\begin{array}{l}-0.013 \\
(0.009)\end{array}$ \\
\hline \multicolumn{5}{|l|}{ Long-run } \\
\hline In_EIMP (LR) & $\begin{array}{l}1.057^{* * *} \\
(0.064)\end{array}$ & $\begin{array}{c}0.708^{* * *} \\
(0.028)\end{array}$ & $\begin{array}{l}1.057^{* * *} \\
(0.064)\end{array}$ & $\begin{array}{l}0.708^{* * *} \\
(0.028)\end{array}$ \\
\hline In_EDOM (LR) & $\begin{array}{l}1.252^{* * *} \\
(0.225)\end{array}$ & $\begin{array}{l}1.534^{* * *} \\
(0.048)\end{array}$ & $\begin{array}{l}1.252^{* * *} \\
(0.225)\end{array}$ & $\begin{array}{l}1.534^{* * *} \\
(0.048)\end{array}$ \\
\hline Error Correction coeff & $\begin{array}{l}-0.045^{* * *} \\
(0.008)\end{array}$ & $\begin{array}{l}-0.062 \text { *** } \\
(0.009)\end{array}$ & $\begin{array}{l}-0.045^{* * *} \\
(0.008)\end{array}$ & $\begin{array}{l}-0.062 \text { *** } \\
(0.009)\end{array}$ \\
\hline \multicolumn{2}{|l|}{ Hausman test } & 1.000 & \multicolumn{2}{|c|}{1.000} \\
\hline OBS & 5,976 & 5,976 & 5,976 & 5,976 \\
\hline
\end{tabular}

Notes: This table reports the baseline error correction model estimation results for three European countries (France, Germany, and the Netherlands) in a pooled manner. The dependent variable in columns (1) - (4) is the country-sector-level monthly producer price (PPI) inflation. Independent variables include country-sector-level monthly effective PPI inflation (EDOM), monthly effective import price inflation (EIMP), and the error correction term. Columns (3) and (4) also include country-sector-level monthly effective unit labor cost inflation (EULC). Columns (1) and (3) report dynamic fixed effects estimation results, whereas columns (2) and (4) report pooled mean group estimation results. Estimates on the error correction coefficient and p-values from the Hausman test are reported at the bottom of the table. Robust standard errors are in parentheses. Significance: * 10 percent; ** 5 percent; *** 1 percent.

in the long run. Although the short-run cost pass-through of domestic inputs is somewhat lower than that for imported inputs at 56 percent, near-perfect pass-through of domestic inputs in the long run cannot be rejected either. Lastly, reflecting the second and the third facts above, the speed of the adjustment is also about three times bigger than that of Korea, implying faster adjustments of producer prices toward the long-run relationship with input prices.

This exercise illustrates the generalizability of the methodology employed in the paper, but at the same time it suggests substantial heterogeneity in the degree 
Table 6: Extended Error Correction Model (ECM) Estimation Results for Selected European Countries

\begin{tabular}{|c|c|c|c|c|}
\hline & (1) & (2) & (3) & (4) \\
\hline & DFE & PMG & DFE & PMG \\
\hline \multicolumn{5}{|l|}{ Short-run } \\
\hline \multirow[t]{2}{*}{$\Delta$ In_EIMP it (SR) } & $0.854^{* * *}$ & $0.628^{* * *}$ & $0.854^{* * *}$ & $0.624^{* * *}$ \\
\hline & $(0.207)$ & $(0.085)$ & $(0.206)$ & $(0.007)$ \\
\hline \multirow[t]{2}{*}{$\Delta \mathrm{In} \_E D O M_{i t}(S R)$} & 0.237 & $0.330^{*}$ & 0.236 & $0.347^{*}$ \\
\hline & $(0.241)$ & $(0.171)$ & $(0.241)$ & $(0.178)$ \\
\hline$\Delta \mathrm{In} \_E U L C_{\text {it }}(\mathrm{SR})$ & & & $\begin{array}{r}0.000 \\
(0.002)\end{array}$ & $\begin{array}{r}0.000 \\
(0.011)\end{array}$ \\
\hline$\Delta \mathrm{In} \_E_{-} \mathrm{MP}_{\mathrm{it}-1}(\mathrm{SR})$ & $\begin{array}{l}0.144^{* * *} \\
(0.034)\end{array}$ & $\begin{array}{c}0.181^{*} \\
(0.095)\end{array}$ & $\begin{array}{c}0.144^{* * *} \\
(0.034)\end{array}$ & $\begin{array}{c}0.179^{*} \\
(0.093)\end{array}$ \\
\hline$\Delta \mathrm{In} \_\mathrm{EDOM}_{\mathrm{it}-1}(\mathrm{SR})$ & $\begin{array}{c}0.333^{*} \\
(0.198)\end{array}$ & $\begin{array}{r}0.046 \\
(0.085)\end{array}$ & $\begin{array}{c}0.333^{*} \\
(0.199)\end{array}$ & $\begin{array}{r}0.045 \\
(0.086)\end{array}$ \\
\hline$\Delta \mathrm{In}_{-} E U L C_{\mathrm{it}-1}(\mathrm{SR})$ & & & $\begin{array}{r}0.001 \\
(0.003)\end{array}$ & $\begin{array}{l}-0.011 \\
(0.012)\end{array}$ \\
\hline \multicolumn{5}{|l|}{ Long-run } \\
\hline In_EIMP it (LR) & $\begin{array}{c}1.017^{* * *} \\
(0.063)\end{array}$ & $\begin{array}{l}0.691^{* * *} \\
(0.030)\end{array}$ & $\begin{array}{l}1.017^{* * *} \\
(0.063)\end{array}$ & $\begin{array}{l}0.693^{* * *} \\
(0.030)\end{array}$ \\
\hline In_EDOM It $_{\text {(LR) }}$ & $\begin{array}{l}1.277^{* * *} \\
(0.235)\end{array}$ & $\begin{array}{l}1.578^{* * *} \\
(0.052)\end{array}$ & $\begin{array}{l}1.278^{* * *} \\
(0.235)\end{array}$ & $\begin{array}{l}1.568^{* * *} \\
(0.052)\end{array}$ \\
\hline Error Correction coeff & $\begin{array}{l}-0.044^{* * *} \\
(0.009)\end{array}$ & $\begin{array}{l}-0.060^{* * *} \\
(0.007)\end{array}$ & $\begin{array}{l}-0.044^{* * *} \\
(0.009)\end{array}$ & $\begin{array}{l}-0.059^{* * *} \\
(0.007)\end{array}$ \\
\hline \multicolumn{5}{|l|}{ Hausman test } \\
\hline OBS & 5,887 & 5,887 & 5,887 & 5,887 \\
\hline
\end{tabular}

Notes: This table checks the robustness of the baseline error correction model estimation results for three European countries (France, Germany, and the Netherlands). The dependent variable in columns (1) - (4) is the sector-level monthly producer price (PPI) inflation. Independent variables include sector-level monthly effective PPI inflation (EDOM), monthly effective import price inflation (EIMP), sector-level monthly effective unit labor cost inflation (EULC) and their one-period lagged terms as well as the error correction term. Columns (1) and (3) report dynamic fixed effects estimation results, whereas columns (2) and (4) report pooled mean group estimation results. Estimates on the error correction coefficient and p-values from the Hausman test are reported at the bottom of the table. Robust standard errors are in parentheses. Significance: * 10 percent; ** 5 percent; *** 1 percent.

of import price pass-through across countries. Such heterogeneity potentially reflects different market structures. It is perhaps not surprising to find more flexible price adjustment dynamics in these European countries than in Korea, as it is conceivable that this systematic difference might stem from higher competition and more flexible market. We leave the question for future study. 


\section{IV . Conclusion}

Motivated by the stylized facts that suggest a dominant role of imported inputs in transmitting exchange rate shocks to domestic prices, this paper studies the imported input cost pass-through to domestic producer prices, using sector-level data. Given the nonstationary nature of price series, this study employs the error correction model (ECM) estimation approach and checks for potential heterogeneity in the degree of pass-through across sectors. In the process, we construct effective import price and domestic input price indices by incorporating bilateral sector-level information on input-output linkages. The current methodology greatly helps to pin down a consistent and efficient estimate of the degree of pass-through from imported input prices to domestic producer prices. We find intriguing evidence on systematic cross-country variation in the degree of imported input cost pass-through, which is left to be explained for future studies. 


\section{References}

Ahn, JaeBin, and Chang-Gui Park (2014), "Exchange Rate Pass-Through to Domestic Producer Prices: Evidence from Korean Firm-level Pricing Survey," Economics Letters, Vol. 125(1), pp. 138-142.

Amiti, Mary, and Jozef Konings (2007), "Trade Liberalization, Intermediate Inputs, and Productivity: Evidence from Indonesia," American Economic Review, Vol. 97(5), pp. 1611-1638.

Amiti, Mary, Oleg Itskhoki, and Jozef Konings (2014), "Importers, Exporters, and Exchange Rate Disconnect," American Economic Review, Vol. 104(7), pp. 1942-1978.

Auer, Raphael, and Aaron Mehrotra (2014), "Trade Linkages and the Globalization of Inflation in Asia and the Pacific," Journal of International Money and Finance, Vol. 49(A), 129-151.

Burstein, Ariel, and Gita Gopinath (2014), International Prices and Exchange Rates, Handbook of International Economics, 4th ed. Elsevier, pp. 391-451.

Campa, José, and Linda Goldberg (2005), "Exchange Rate Pass-Through into Import Prices," Review of Economics and Statistics, Vol. 87(4), pp. 679-690.

Cha, Hye Kyung (2012), "Analysis on the Low Exchange Rate Pass-through to CPI," Korean Journal of Public Finance, Vol. 14(3), pp. 35-61.

Corsetti, Giancarlo, and Paolo Pesenti (2005), "International Dimensions of Optimal Monetary Policy," Journal of Monetary Economics, Vol. 52(2), pp. 281-305.

Devereux, Michael, and Charles Engel (2003), "Monetary Policy in the Open Economy Revisited: Price Setting and Exchange Rate Flexibility," Review of Economic Studies, Vol. 70(4), pp. 765-783. 
Devereux, Michael, and Charles Engel (2003), "Expenditure Switching versus Real Exchange Rate Stabilization: Competing Objectives for Exchange Rate Policy," Journal of Monetary Economics, Vol. 54(8), pp. 2346-2374.

Goldberg, Linda, and José Campa (2010), "The Sensitivity of the CPI to Exchange Rates: Distribution Margins, Imported Inputs, and Trade Exposure," Review of Economics and Statistics, Vol. 92(2), pp. 392-407.

Im, Kyung So, Hashem Pesaran, and Yongcheol Shin (2003), "Testing for Unit Roots in Heterogeneous Panels," Journal of Econometrics, Vol. 115(1), pp. 53-74.

International Monetary Fund (2015), "Cross-Country Report on Inflation," IMF Country Report No.15/184 (Washington).

Iossifov, Plamen, and Jiri Podpiera (2014), “Are Non-Euro Area EU Countries Importing Low Inflation from the Euro Area?" IMF Working Paper 14-191 (Washington: International Monetary Fund).

Kim, Ki-Ho (2012), "Analysis on the Foreign Price Pass-through to Domestic Prices," Bank of Korea Discussion Paper Series, No. 2012-14.

Lee, Jae Woo (1997), "The Response of Exchange Rate Pass-Through to Market Concentration in a Small Economy: The Evidence from Korea," Review of Economics and Statistics, Vol. 79(1), pp. 142-145.

Obstfeld, Maurice, and Kenneth Rogoff (2000), "New Directions for Stochastic Open Economy Models," Journal of International Economics, Vol. 50(1), pp. 117-153.

Topalova, Petia, and Amit Khandelwal (2011), "Trade Liberalization and Firm Productivity: The Case of India," Review of Economics and Statistics, Vol. 93(3), pp. 995-1009. 


\section{$<$ Abstract in Korean $>$}

\section{산업별 수입 투입재 물가의 생산자 물가에 대한 전가율 분석}

\section{안재빈 ${ }^{*}$, 박창귀 ${ }^{* *}$, 박찬호***}

본 연구는 국제적인 supply chain 강화 등으로 국내 제품 생산과정에 수입원자재 투입이 증가되면서 생산에 사용된 수입 원자재 경로가 생산자 물가에 미치는 영향이 커지고 있음에 주목하였다. 이에 본 논문에서는 수입물가지수 및 생산자 물가지수에 I-O table의 수입 및 국내 투입재 비율을 적용하여 산업별 수입 투입재 물가지수와 국내 투입재 물가지수를 구축한 후 수입 및 국내 투입재 물가와 생산자 물가 간의 관계 등을 분석하였다.

오차수정모형(ECM) 등을 이용하여 전가율을 추정한 결과, 수입 투입재 물가의 생산자 물가에 대한 단기전가율은 $37 \sim 41 \%$, 장기전가율은 $67 \sim 70 \%$ 로, 국내 투입재 물가의 생산자 물가에 대한 단기전가율은 $40 \sim 42 \%$, 장기전가율은 $79 \sim 86 \%$ 로 나타났다. 한편 동일한 방법론을 프랑스, 독일, 네덜란드에 적용하여 분석해본 결과 수입 투입재 물가의 생산자 물가에 대한 단기전가율은 $90 \%$, 장기전가율은 거의 $100 \%$ 에 가까운 것으로 추정되었으며, 국내 투입재 물가의 생산자 물가에 대한 단기전가율은 $56 \%$, 장기전가율은 거의 $100 \%$ 로 각각 한국의 경우보다 높은 것으로 분석되었다.

핵심주제어: 환율전가, 수입재 투입비용 전가, 인플레이션 JEL Classification: E3, F3,F4

\footnotetext{
* IMF economist

** 한국은행 대전충남본부 경제조사팀장

*** 한국은행 국제국 국제금융부장
}

이 연구내용은 집필자의 개인의견이며 한국은행의 공식견해와는 무관합니다. 따라서 본 논문의 내용을 보도하거나 인용할 경우에는 집필자명을 반드시 명시하여 주시기 바랍니다. 